\title{
Repeated generalized seizures shortly after single intramuscular dose is an additional reasonable cause to restrict the use of ondansetron: A case report
}

\author{
Azza H. AbouGhalia*, Hanan H. Shehata \\ Biochemistry department, Faculty of medicine, Ain Shams University, Abbassia, Cairo, Egypt \\ Email: ${ }^{*}$ azzaaboghalia@yahoo.com
}

Received 3 September 2013; revised 2 October 2013; accepted 15 October 2013

Copyright (c) 2013 Azza H. AbouGhalia, Hanan H. Shehata. This is an open access article distributed under the Creative Commons Attribution License, which permits unrestricted use, distribution, and reproduction in any medium, provided the original work is properly cited.

\begin{abstract}
Background: Ondansetron, a 5-hydroxytryptamine (5-HT) receptor antagonist, is generally regarded as a safe and well tolerated antiemetic. Meanwhile, some reports mentioned that it is a probable cause of single generalized seizures after intravenous administration. Our report may be the first to indicate repeated generalized seizures after intramuscular therapeutic dose of ondansetron. Methods and Results: We report a 24-year-old female with nausea and vomiting related to gastritis that experienced repeated ondansetroninduced seizures shortly after a single intramuscular therapeutic dose. Two minutes after intramuscular injection of $4 \mathrm{mg}$ ondansetron, our patient developed the first generalized seizure. Within the following two hours, seizures occurred two more times. In the emergency department, the patient developed a fourth, but weaker and shorter, generalized seizure. The patient was not hypoglycemic, but her blood hemoglobin and serum electrolytes were below normal. A few hours later, the patient was discharged. The dramatic onset of the seizures, as well as the complete recovery and absence of any neurological sequel in our patient, indicated that it was probably related to ondansetron. Conclusion: Patients should be informed about the potential side effects of ondansetron especially the lifethreatening repeated generalized seizures, and clinicians should restrict its use to hospitalized patients.
\end{abstract}

Keywords: Ondansetron; Seizures;

5-Hydroxytryptamine Receptor Antagonist

\section{INTRODUCTION}

Ondansetron (zofran) a selective 5-hydroxytryptamine

"Corresponding author.
(5-HT3) receptor antagonist is frequently used to treat severe nausea and vomiting associated with cancer chemotherapy, radiotherapy, anesthesia, surgery as well as drug over-dosage or poisoning [1].

\section{Case Report}

A single dose of $4 \mathrm{mg}$ ondansetron was intramuscularly injected to a 24-year-old female. Two days before administration of ondansetron, she received oral domperidone (motilium) as $5 \mathrm{mg}$ tablets twice daily to control vomiting related to gastritis. The patient had no previous history of seizures, head injury or meningitis. She developed four generalized tonic-clonic seizures; the first one occurred within two minutes after the injection. Within the following two hours, seizures occurred two more times. The time lasting between the first and second seizures was about thirty minutes. The patient's body weight was $60 \mathrm{Kg}$. The blood pressure and pulse rate were $90 / 60 \mathrm{mmHg}, 60 /$ minute, respectively. In the emergency clinic, the patient developed a fourth, but weaker and shorter, generalized seizure. She received intravenous rehydration therapy in the form of $500 \mathrm{~mL}$ of ringer followed by $500 \mathrm{ml}$ of normal saline. Her random blood glucose level was $80 \mathrm{mg} / \mathrm{dl}$ as checked by a glucometer. The acid base properties, liver function tests, serum creatinine and blood urea nitrogen were all normal. The total hemoglobin $(11.1 \mathrm{~g} / \mathrm{dL}$ ), serum electrolytes (sodium $133 \mathrm{mmol} / \mathrm{L}$, potassium $3 \mathrm{mmol} / \mathrm{L}$ and calcium 0.87 $\mathrm{mmol} / \mathrm{L}$ ) were below the reference limits (Sodium: 135 $145 \mathrm{mmol} / \mathrm{L}$; potassium: 3.5 - $5.1 \mathrm{mmol} / \mathrm{L}$; calcium: 1.12 - $1.32 \mathrm{mmol} / \mathrm{L}$ ). The patient as well as her parents refused to have further investigations as electroencephalography (EEG), computed tomography or magnetic resonance imaging, as she remained seizure free without antiepileptic drugs. 


\section{DISCUSSION}

Serotonin 5-HT3 receptors are present in both the central and peripheral nervous systems and are associated with several serotonin-mediated physiological and pathological processes. Ondansetron (a carbazole derivative), is a competitive and selective antagonist of serotonin 5-HT3 receptors. As antiemetics, it decreases vagal activity and inhibits the vomiting center in the medulla oblongata. Also, it decreases the activity of the chemoreceptor trigger zone by blocking the serotonin receptors in the brain. Ondansetron undergoes extensive hepatic oxidative metabolism. Its metabolites contribute little to the activity of the drug and are excreted in the urine and faeces. Renal clearance accounts for less than $5 \%$ of total clearance of this drug. Cytochromes P450 IA2, 2D6 and $3 \mathrm{~A}$ are involved in its hydroxylation. Therefore, in addition to cross-reactivity between ondansetron and agents that compete for these enzymes, toxicity can occur in patients with liver disease [2].

Ondansetron is generally considered as a safer drug than conventional antiemetics. However, many researchers reported a number of potential adverse reactions in relation to this drug. Some of these effects include recurrent bowel occlusion, extrapyramidal manifestations, severe hypoglycemia, hypotension, hypersensitivity reactions as well as acute chorea [1-4]. Thus, Frigerio et al. [5] recommended restriction of ondansetron use.

Using the Naranjo adverse drug reaction probability scale [6], some case reports indicated that ondansetron is a probable cause of single generalized seizures that ap- peared with the intravenous standard dose (as summarized in Table 1).

Domperidone (motilium) is a dopamine-antagonist with anti-emetic function for relieve of symptoms of nausea and vomiting. The Netherlands Pharmacovigilance Centre Lareb received some reports of seizures in association with domperidone [10]. Motilium-induced seizures was ruled out due to intake of oral small dose (5 $\mathrm{mg}$ ), stopping the drug many hours before seizures, as well as absence of seizures with previous intake of the same drug by our patient.

\section{CONCLUSION}

The current as well as previous reports indicate that ondansetron administration is associated with many adverse reactions including seizures. These seizures are not dose-dependent and may start within less than two minutes. It may be single or repeated and can occur with any route of adminstration. Patients should be informed about these potential side effects. Also, physicians should be more cautious while prescribing this medication to out-patients where prompt treatment may not be possible.

\section{BIOETHICAL APPROVAL}

This case study was performed in accordance with Declaration of Helsinki and was approved by the Research Ethics Committee of Ain Shams University, Cairo, Egypt. An informed consent was obtained from the patient.

Table 1. Reports indicating occurrence of generalized seizures after intravenous therapeutic dose of ondansetron.

\begin{tabular}{|c|c|c|c|c|c|c|}
\hline Authors & $\begin{array}{c}\text { No. } \\
\text { Patients }\end{array}$ & $\begin{array}{c}\text { Age } \\
\text { (year)/sex }\end{array}$ & $\begin{array}{c}\text { Dose } \\
\text { (Route of adminstration) }\end{array}$ & $\begin{array}{l}\text { Seizures occurrence } \\
\text { after ondansetron }\end{array}$ & $\begin{array}{l}\text { Number of } \\
\text { seizures }\end{array}$ & $\begin{array}{c}\text { Medical history } \\
\text { (Concomitant medications) }\end{array}$ \\
\hline Patel et al. [1] & 1 & $4 / \mathrm{M}$ & 0.13 mg/kg (I.V.) & 30 minutes & 2 & Gastroenteritis \\
\hline Sharma, Raina [3] & 1 & $55 / \mathrm{F}$ & 4 mg (I.V.) & $\begin{array}{l}\text { First (or third) day of } \\
\text { chemotherapy cycle }\end{array}$ & 1/each cycle & $\begin{array}{l}\text { Metastatic breast cancer } \\
\text { (Chemotherapy) }\end{array}$ \\
\hline Sargent et al. [7] & 1 & $28 / \mathrm{M}$ & 10 mg (I.V.) & 90 minutes & 1 & $\begin{array}{l}\text { Pancreatitis, septic shock, } \\
\text { cardiac arrest } \\
\text { (methadone, Imipenem) }\end{array}$ \\
\hline Mason et al. [8] & 1 & $26 / \mathrm{F}$ & 4 mg (I.V.) & 4 minutes & 1 & $\begin{array}{l}\text { Prophylaxis for postoperative } \\
\text { nausea \& vomiting } \\
\text { (Epidural analgesia, oxytocin) }\end{array}$ \\
\hline \multirow{3}{*}{ Singh et al. [9] } & \multirow{3}{*}{3} & $36 / \mathrm{F}$ & 4 mg (I.V.) & 12 minutes & 1 & Migraine (Tylenol, Motrin) \\
\hline & & $56 / \mathrm{F}$ & 4 mg (I.V.) & 15 minutes & 1 & $\begin{array}{l}\text { Diabetic ketoacidosis } \\
\text { (Insulin, metformin) }\end{array}$ \\
\hline & & $46 / \mathrm{M}$ & 4 mg (I.V.) & 22 minutes & 1 & Gastritis (Cetirizine) \\
\hline
\end{tabular}




\section{ACKNOWLEDGEMENTS}

The corresponding author wish to thank Dr. Hassan Ahmed Hassan AbouGhalia; Suez Canal University for his great help in writing this case report.

\section{REFERENCES}

[1] Patel, A., Mittal, S., Machanda, S. and Puliyel, J.M. (2011) Ondansetron-induced dystonia, hypoglycemia, and seizures in a child. Annals of Pharmacotherapy, 45, e7. http://dx.doi.org/10.1345/aph.1P332

[2] Cooke, C.E. and Mehra, I.V. (1994) Oral ondansetron for preventing nausea and vomiting. American Journal of Hospital Pharmacy, 51, 762-771.

[3] Sharma, A. and Raina, V. (2001) Generalized seizures following ondansetron. Annals of Oncology, 12, 131-132. http://dx.doi.org/10.1023/A:1008394422101

[4] Mehra, K.K., Gogtay, N.J., Ainchwar, R. and Bichile, L.S. (2008) Hypersensitivity to intravenous ondansetron: A case report. Journal of Medical Case Reports, 2, 274. http://dx.doi.org/10.1186/1752-1947-2-274
[5] Frigerio, C., Buchwalder, P.A. and Spertini, F. (1996) Ondansetron: Reasons to be restrictive. Lancet, 347, 584585. http://dx.doi.org/10.1016/S0140-6736(96)91720-1

[6] Naranjo, C.A., Busto, U., Pharm. D., et al (1981) A method for estimating the probability of adverse drug reactions. Clinical Pharmacology \& Therapeutics, 30, 239245. http://dx.doi.org/10.1038/clpt.1981.154

[7] Sargent, A.I., Deppe, S.A. and Chan, F.A. (1993) Seizure associated with ondansetron. Clinical Pharmacology \& Therapeutics, 12, 613-615.

[8] Mason, C.L., Munnur, U. and Suresh, M. (2007) Generalized seizure following ondansetron adminstration during cesarean section. Anesthesiology, 106, 105.

[9] Singh, N.N., Rai, A., Selhorst, J.B. and Acharya, J.N. (2009) Ondansetron and seizures. Epilepsia, 50, 26632666. http://dx.doi.org/10.1111/j.1528-1167.2009.02139.x

[10] Weaving, A., Bezwoda, W.R. and Derman, D.P. (1984) Seizures after antiemetic treatment with high dose domperidone: Report of four cases. British Medical Journal (Clinical Research Ed.), 288, 1728. http://dx.doi.org/10.1136/bmj.288.6432.1728 